\title{
Geomorphic History of the Beaver Creek Drainage Basin as Determined from Topographic Map Evidence: Eastern Montana and Western North Dakota, USA
}

\author{
Eric Clausen ${ }^{1}$ \\ ${ }^{1}$ Independent Investigator, Jenkintown, PA 19046, United States \\ Correspondence: Eric Clausen, Independent Investigator, Jenkintown, PA 19046, United States. E-mail: \\ eric2clausen@gmail.com
}

Received: August 1, 2018

Accepted: August 21, 2018

Online Published: August 26, 2018

doi:10.5539/jgg.v10n3p79

URL: http://dx.doi.org/10.5539/jgg.v10n3p79

\begin{abstract}
The Beaver Creek drainage basin is located along the North Dakota-Montana border slightly to the south of a recognized continental ice sheet margin and immediately to the east of the deep northeast-oriented Yellowstone River valley with Beaver Creek flowing in a north and northeast direction to join the north-oriented Little Missouri River. The Beaver Creek drainage basin originates on an escarpment-surrounded upland and its erosional history was determined by analyzing detailed topographic maps aided by previously made field observations that showed coarse-grained and distinctive alluvium had been transported in an east direction across the Beaver Creek drainage basin and across what is now the deep Little Missouri River valley to sediments making up southwest North Dakota high points containing both the distinctive alluvium and Oligocene age fossils. Drainage divides surrounding the Beaver Creek drainage basin show numerous divide crossings (or notches) linking northwest-oriented Yellowstone River tributary valleys with east-oriented Beaver Creek tributary valleys and west- or northwest-oriented Beaver Creek tributary valleys with southeast- or east-oriented Little Missouri River tributary valleys and suggest the Beaver Creek valley eroded headward across a large-scale flood formed anastomosing channel complex. Buttes located just to the east of the Beaver Creek-Little Missouri River drainage divide suggest the east-oriented water removed as much as 150 meters, or more, of Beaver Creek drainage basin bedrock, and even greater amounts of bedrock from regions to the south of the Beaver Creek drainage basin. Topographic map evidence and routes traveled by the distinctive alluvium suggest a continental ice sheet blocked a large and high-level northeastoriented river and diverted at least some of the water along the ice sheet margin with the east-oriented floodwaters being captured in a progressive sequence by headward erosion of the Little Missouri River, Beaver Creek, and Yellowstone River valleys (in that order).
\end{abstract}

Keywords: barbed tributaries, continental ice sheet melt water erosion, drainage divides, escarpment-surrounded upland, Little Missouri River, Missouri River, Yellowstone River

\section{Introduction}

Beaver Creek is a northwest-, north-, and northeast-oriented tributary to the Little Missouri River and drains a Montana-North Dakota border region located between the north-oriented Little Missouri River and the northeastoriented Yellowstone River. What makes the Beaver Creek drainage basin particularly interesting is the drainage basin's southern half is located on an escarpment-surrounded upland. A southeast-facing escarpment at the Beaver Creek drainage basin's southern end slopes down into the deep Little Missouri River valley and a southwest-facing escarpment slopes down into the deep northwest-oriented Cabin Creek valley, with Cabin Creek draining to the northeast-oriented Yellowstone River. Further to the north a west-facing escarpment marks the drainage basin's western boundary and an east-facing escarpment marks its eastern boundary. These escarpments become less noticeable further to the north especially after Beaver Creek turns in a northeast direction and begins to flow in a deeper valley before joining the north-oriented Little Missouri River. How did the Beaver Creek drainage basin originate and how does its escarpment-surrounded upland's geomorphic history relate to the adjacent Little Missouri River and Yellowstone River valleys?

Figure 1 uses a modified map from the United States Geological Survey (USGS) National Map website and the red rectangle identifies this paper's study region located along the North Dakota-Montana border and between the 
north-oriented Little Missouri River and the northeast-oriented Yellowstone River. Red letters identify major drainage routes as follows: B-Belle Fourche River, C-Cheyenne River, Cb-Cannonball River, H-Heart River, LLittle Missouri River, M-Missouri River, P-Powder River, R-Redwater River, and Y-Yellowstone River. The Little Missouri River and Yellowstone River are tributaries to the east- and south-oriented Missouri River with water eventually reaching the Gulf of Mexico. Note how the Missouri River flows in an easterly direction across northeast Montana before entering North Dakota where the river gradually turns to flow in a south direction. The North American north-south continental divide is located a short distance to the north and east of this Missouri River segment and crosses the northeast corner of figure 1. The Missouri River segment shown in figure 1 is usually thought to have formed along a continental ice sheet's southwest boundary and abundant coarse- and finegrained glacially deposited sediments are common to the north and east of the Missouri River valley, although scattered coarse-grained glacial erratic material can be found as much as 60 kilometers to the south and west of the present day Missouri River valley.

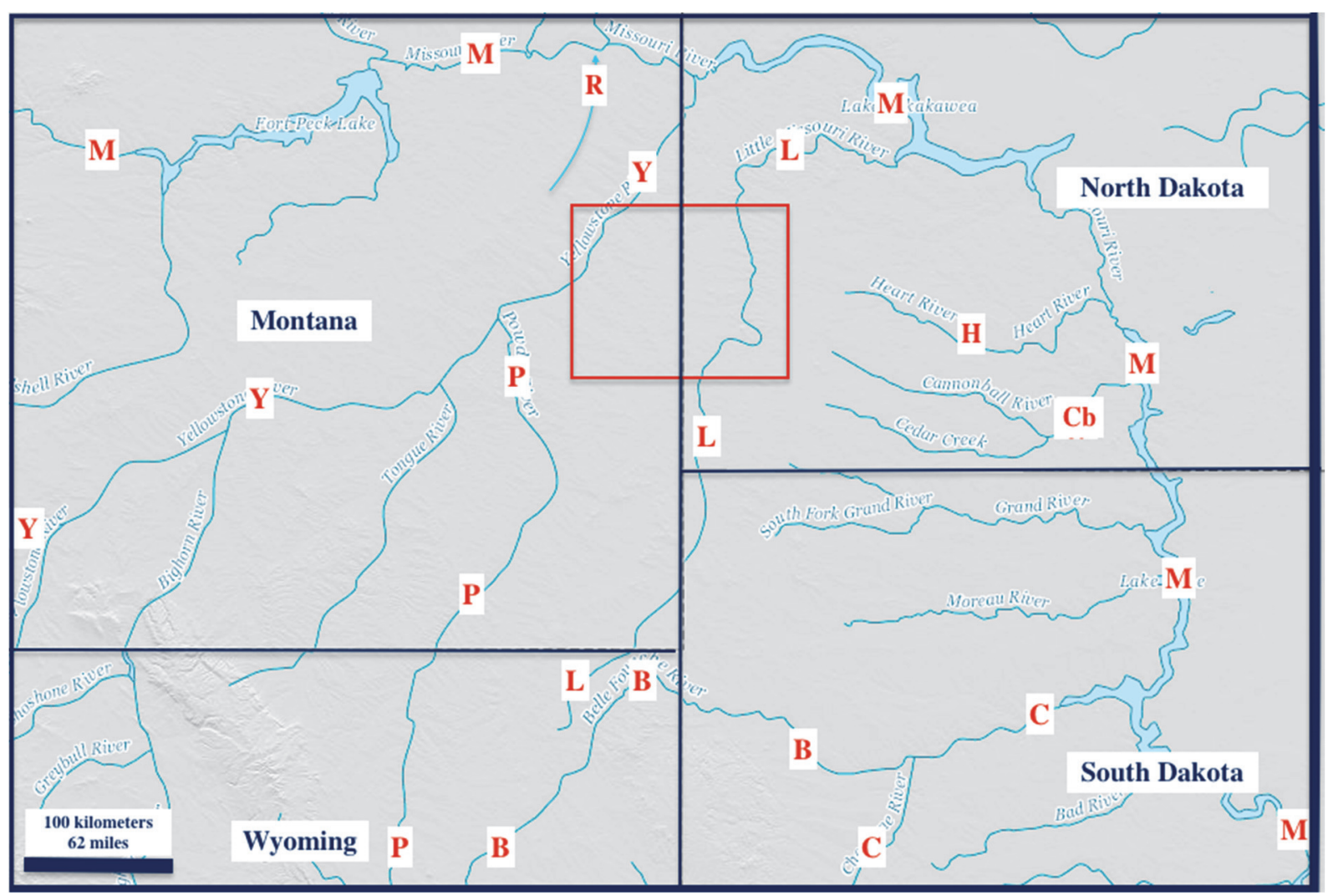

Figure 1. Modified map from the United States Geological Survey (USGS) National Map website with a red rectangle showing the study region location. Rivers are identified as follows: B-Belle Fourche River, C-

Cheyenne River, Cb-Cannonball River, H-Heart River, M-Missouri River, P-Powder River, R-Redwater River, and Y-Yellowstone River

Figure 2 uses a more detailed map from the USGS National Map website to show major drainage routes within and near this paper's study region where Beaver Creek is identified by "BC", Cabin Creek by "CB", the Little Missouri River by "L", O'Fallon Creek by "O", Sandstone Creek by "S", and the Yellowstone River by "Y". Note how many Yellowstone River tributaries are oriented in either northwest or southeast directions. More detailed maps show additional drainage routes including northwest-oriented streams and southeast-oriented barbed tributaries flowing to Beaver Creek's north- and northeast-oriented segments. This pattern of northwest- and southeast-oriented tributaries is not unique to Beaver Creek, but is also seen along the Little Missouri River and most other north-oriented drainage routes located to the south and west of the Missouri River valley. Clausen (2017a, 2017b) attributes the pattern of northwest- and southeast-oriented tributaries to the headward erosion of the north-oriented valleys (in sequence from the southeast to the northwest) across massive southeast-oriented icemarginal melt water floods. However most previous researchers regard the north-oriented Missouri River 
tributaries to have formed as components of a large pre-glacial north-oriented drainage system named as the Bell River drainage system, which is illustrated in McMillan (1973), Duk-Rodkin and Hughes (1994), and Sears (2013).

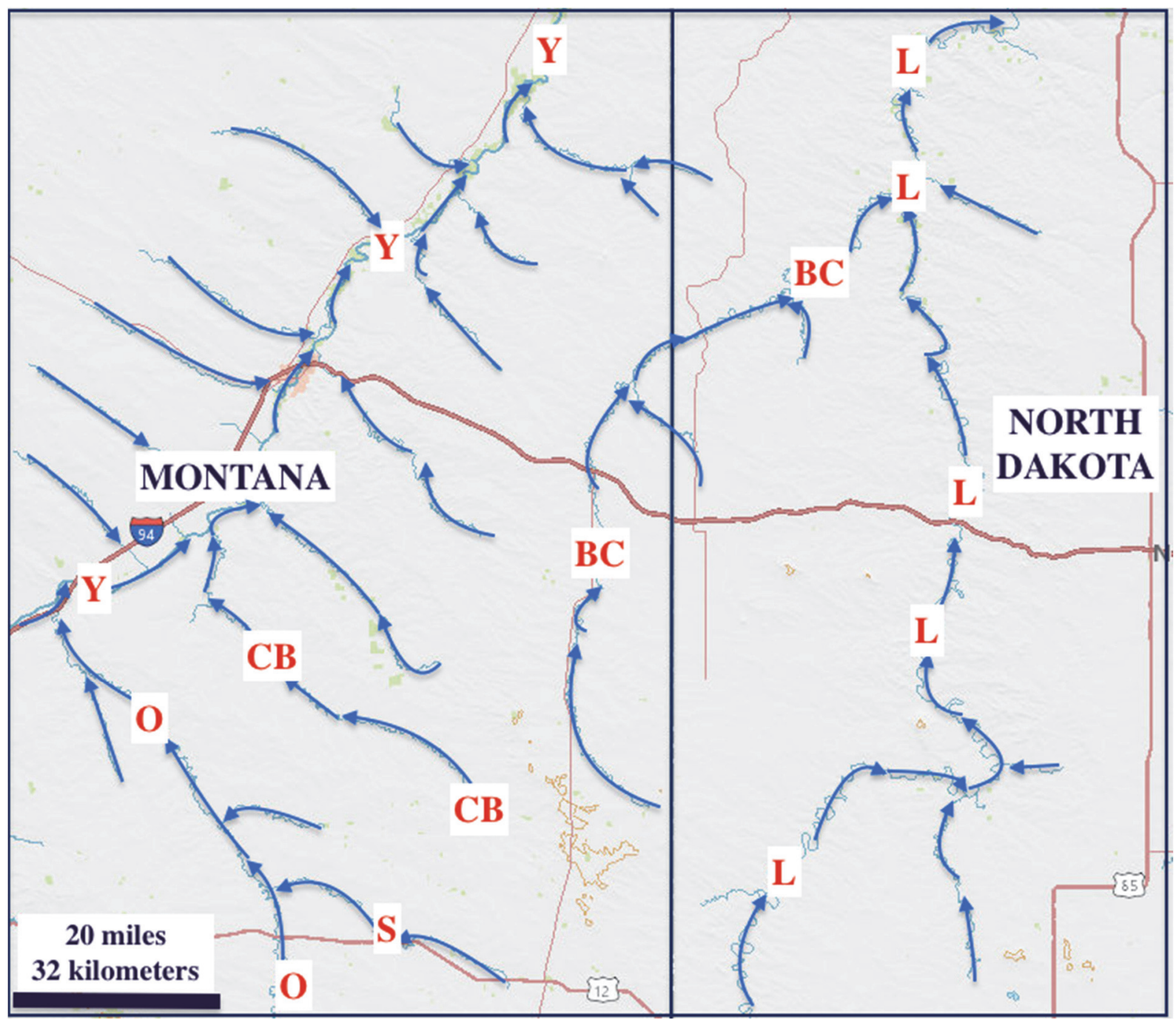

Figure 2. Modified map from the USGS National Map website showing the Beaver Creek (BC) location between the north-oriented Little Missouri River (L) and the northeast-oriented Yellowstone River (Y). Cabin Creek (CB), O'Fallon Creek (O), and Sandstone Creek (S) are the labeled northwest-oriented Yellowstone River tributaries

While previous workers have not addressed northwest-to-southeast oriented drainage routes found in the Beaver Creek region Thornbury (1965) discusses how investigators have noticed at "various localities throughout the Great Plains a remarkable northwest-southeast alignment of streams." These earlier investigations were in regions other than this paper's study region, but discuss a phenomenon similar to that observed here. Russell (1929) suggested streams originally followed depressions between longitudinal dunes, although the dunes have now largely disappeared. Flint (1955) who worked in South Dakota considered wind action as the most likely aligned drainage cause. Crandell (1958) concluded stream alignment in central South Dakota is related to the prevailing northwesterly winds. Since Thornbury's book Whitney (1985) has suggested aligned streams originated in depressions between wind-formed yardangs. Lineaments and joints have also been used to explain some aligned drainage features. For example Shurr (1982) used aligned drainage surrounding the northern Black Hills area located to the south of this paper's study region to suggest the presence of subsurface lineaments.

Recent surface geologic maps of Montana Beaver Creek drainage basin areas (Vuke et al, 2003, and Vuke and Colton, 1998) and of the North Dakota Beaver Creek drainage basin area (Carlson, 1983) show most of the region to be underlain by the Paleocene Tongue River Formation or Fort Union Formation member (interbedded sand, 
silt, clay, and lignite) or the underlying Paleocene Ludlow Formation or Fort Union Formation member (also interbedded sand, silt, clay, and lignite). Vuke et al and Vuke and Colton also show scattered surface deposits of clinker (baked clays formed by the burning of underlying lignite beds) and the presence of Quaternary alluvial terrace deposits generally on the west side of the north-oriented Beaver Creek valley while Carlson shows isolated Oligocene White River group deposits capping buttes to the east of the Beaver Creek drainage basin. The Geologic Map of North Dakota (Clayton, et al, 1980) shows in the Beaver Creek drainage basin two surface alluvium deposits labeled QTU (Quaternary and upper Tertiary sediment, undivided). The Geologic Map of North Dakota also shows the southern limit of mapped glacial erratic material is approximately 20 kilometers to the north of where Beaver Creek joins the north- and east-oriented Little Missouri River.

Possibly important to understanding Beaver Creek drainage basin geomorphic history are reports that continental ice sheets blocked the hypothesized pre-glacial north-oriented Little Missouri and northeast-oriented Yellowstone Rivers. Howard (1960), who worked in the area immediately to the north of the Beaver Creek drainage basin, discusses evidence for the presence of a Glacial Lake Glendive in what he considered to be a pre-glacial Yellowstone River valley and of a Glacial Lake Mikkleson in what he considered to be a pre-glacial Little Missouri River valley. Most of the Beaver Creek drainage basin is at a higher elevation than those two glacial lakes (assuming the lakes existed as described). Evidence for those lakes is primarily based on the assumption that the Yellowstone and Little Missouri River valleys at least to some extent were eroded in pre-glacial time and also on what are interpreted to be possible lake outlets plus a report of one possible Glacial Lake Glendive deltaic deposit (Colton and Fullerton, 1986). Other investigators, including this author, use the lack of identifiable shorelines and the absence of extensive lake deposited sediments to question whether Glacial Lakes Glendive and Mikkleson existed (at least as described). Well-defined shorelines developed within a few years after reservoirs behind Missouri River valley dams had filled and if Glacial Lakes Glendive and Mikkleson existed as described similar shorelines should have been formed and at least some evidence of those shorelines should exist today.

During the 1980s while conducting field work partially reported in Clausen (1989) it was determined that the QTU alluvial deposits in the Beaver Creek drainage basin contain some of the same distinctive rock types as are found in QTU alluvium to the east of the deep north-oriented Little Missouri River valley and also found in alluvial deposits named by Howard (1958) as the Rimroad Gravel that are located on the high drainage divide to the northwest of the deep northeast-oriented Yellowstone River valley. In addition Clausen determined the distinctive Rimroad Gravel rock types were also common in alluvial deposits containing Oligocene fossils that underlie White Butte, North Dakota's highest point. The same distinctive rock types are also common in mapped QTU sediments surrounding the White Butte base and are found in elongate east- and southeast-oriented alluvial trails roughly paralleling the mapped southwest limit of glacial erratic material. While not directly stated in Clausen's paper this evidence suggests a continental ice sheet margin blocked or partially blocked a large northeast-oriented river, that was flowing at an elevation equivalent to the high drainage divide to the northwest of the present day deep northeast-oriented Yellowstone River valley, and significant volumes of water were then diverted along the ice sheet margin.

\section{Research method}

The study reported here is one component of the author's much larger Missouri River drainage basin landform origins research project. Preliminary topographic map analysis leading to the larger project was initiated following a determination that distinctive igneous rocks contained in the mapped North Dakota QTU and Oligocene White River deposits had been derived from the Yellowstone River drainage basin as opposed to a possible Black Hills source area that early vertebrate paleontologists (e. g. Douglas, 1909) first suggested. Denson and Gill (1965) reported the distinctive alluvium did not match Black Hills rock types, although literature published since 1965 (e.g. Stone, 1973) assumes the Black Hills to have been the source area. While distinctive alluvium trails found by Clausen suggest a continental ice sheet margin blocked a large northeast-oriented river and diverted at least some of the water in an east and southeast direction commonly accepted geologic histories suggest there is a 30 million year time gap between when the Oligocene White River sediment and fossil deposition occurred and the onset of North American continental ice sheets. The distinctive alluvium trails suggest the two events were simultaneous, meaning from the commonly accepted regional middle and late Cenozoic geologic history paradigm perspective a continental ice sheet margin cannot explain the distinctive alluvium trail evidence.

Recognizing the presence of anomalous evidence, or evidence the commonly accepted geologic history paradigm cannot adequately explain, is much easier than finding a new paradigm that does explain the evidence. Sediment and fossil evidence (including glacially deposited sediments) was used to develop the commonly accepted geologic history paradigm and this author's expertise is in regional geomorphology with topographic map interpretation skills and not in sedimentology or paleontology. However, many years ago Arthur Strahler, then at Columbia 
University, and Brainerd Mears, then at the University of Wyoming, introduced this author to unsolved erosional landform origin problems (some are described in Thornbury's 1965 book) and previous efforts by this author to solve those landform origin problems kept leading to more unsolved landform origin problems and eventually to a realization that most erosional landform origins are not adequately explained. Finally, after recognizing the commonly accepted late Cenozoic geologic history paradigm could not explain the distinctive alluvium trail evidence and almost all regional erosional landform origins, a decision was made to construct a new regional middle and late Cenozoic geologic history paradigm from the unexplained or anomalous erosional landform evidence.

The new paradigm is described in some of Clausen's recent papers (e.g. 2018a) and was first constructed by systematically studying mosaics of detailed topographic maps of the entire Missouri River and adjacent drainage basin areas to determine how the observed drainage divides had been created. That 3-year project used valleys crossing drainage divides, barbed tributaries and other stream capture evidence, valley orientations, and similar evidence to reconstruct pre-Missouri River drainage basin drainage routes. The reconstructed pre-Missouri River drainage basin routes showed a fundamentally different continental ice sheet and Missouri River drainage basin history than anything previous investigators had considered, however the evidence was on large mosaics of detailed topographic maps and for publication purposes was almost impossible to illustrate. When digital topographic maps became available the project was repeated during the 2011-2013 time period using National Geographic TOPO software with project research notes and maps related to those notes presented in blog format at geomorphologyresearch.com. Briefly the new paradigm describes how the entire Missouri River drainage system developed as deep valleys eroded headward across immense continental ice sheet melt water floods and how those floods flowed across rising mountain ranges and plateaus.

New paradigm development processes are described in Thomas Kuhn's (1970) book “The Structure of Scientific Revolutions" and involve the discovery and recognition of unexplained or anomalous evidence and the new paradigm in this case was constructed from large quantities of such evidence. From the commonly accepted paradigm's perspective some new paradigm rules and resulting conclusions appear to be impossible and vice versus. However, according to Kuhn paradigms by themselves are neither correct nor incorrect, and one paradigm cannot be judged from another paradigm's perspective. Instead to be accepted a new paradigm must demonstrate its ability to open up productive new research directions, which usually occurs when large quantities of previously unexplained evidence are recognized and explained for the first time. This paper, which focuses on the Beaver Creek drainage basin area, is one of several papers being written and submitted for publication to illustrate how by following the new paradigm rules large numbers of previously unexplained erosional landform origins can easily be determined.

New paradigm rules most applicable to the Beaver Creek drainage basin location are that at least one North American continental ice sheet created and occupied a deep "hole" and as that ice sheet melted space in the deep "hole's" southern end was opened up enabling deep north- and northeast-oriented valleys to erode headward across immense southeast-oriented ice-marginal melt water floods so as to divert the ice-marginal floodwaters onto and across the melting ice sheet's floor. In the case of this paper's study region these new paradigm rules require southeast-oriented ice-marginal melt water floods to have flowed across the entire Beaver Creek drainage basin and adjacent areas and to have been captured in sequence by headward erosion of the north-oriented Little Missouri River, the north-oriented Beaver Creek, and the northeast-oriented Yellowstone River valleys. The study reported here used detailed topographic maps available at the USGS National Map website to determine whether the new paradigm requirements provide explanations for observed Beaver Creek drainage basin landform evidence and is a demonstration of how the new paradigm rules can be used to explain previously unexplained landform origins.

\section{Results}

\subsection{Beaver Creek Tributaries and Their Orientations}

Figure 3 illustrates north-oriented Beaver Creek and the Yellowstone River-Beaver Creek drainage divide in the region to the north of Wibaux, Montana. In this region Beaver Creek is located very close to the Yellowstone RiverBeaver Creek drainage divide. Note how northwest-oriented Yellowstone River tributaries originate along the drainage divide's western side while much shorter southeast- and east-oriented Beaver Creek tributaries originate along the drainage divide's eastern side. Also note how much longer northwest-oriented tributaries join Beaver Creek from the east. Little Beaver Creek (LB in figure 3) originates as a north-oriented stream (seen in a later figure) and then turns to flow in a northwest direction as seen in figure 3 . As previously mentioned in the region to the south and west of the Missouri River tributaries to major north- and northeast-oriented drainage routes are frequently oriented in northwest or southeast directions as are many, but not all Beaver Creek tributaries. Barbed 
tributaries such as the southeast-oriented streams joining north-oriented Beaver Creek indicate headward erosion of the north-oriented Beaver Creek valley captured southeast-oriented drainage routes. Northwest-oriented tributaries could develop during such capture events, but only if the capturing stream valley was much deeper than valley of the drainage route being captured and if the captured drainage route's gradient was very low. Under such circumstances water at the northwest end of the beheaded drainage route could reverse its flow direction and move toward the newly eroded and much deeper capturing valley.

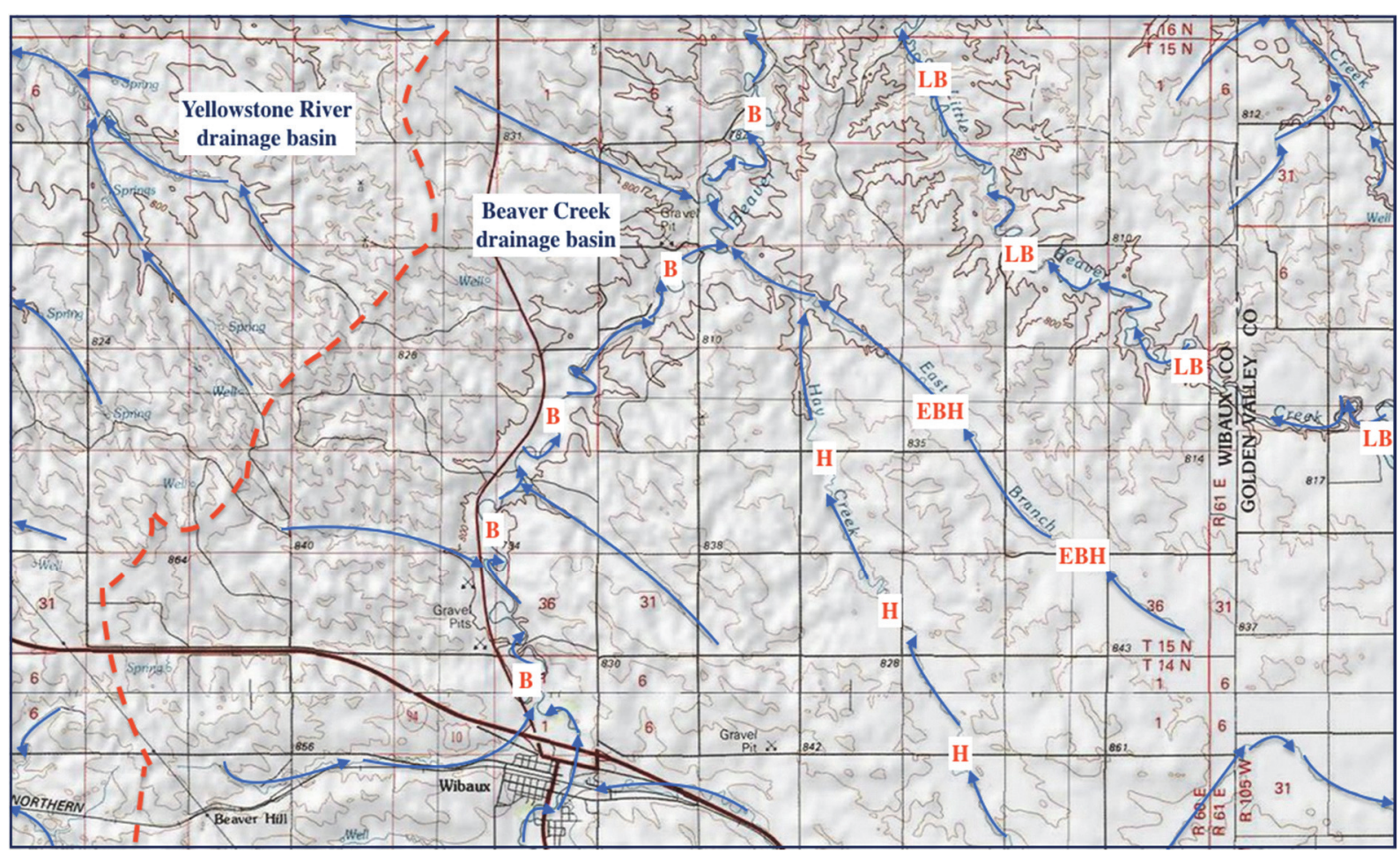

Figure 3. Modified topographic map from the USGS National Map website of an area to the north of Wibaux, Montana showing tributary orientations along the Yellowstone River-Beaver Creek drainage divide (shown with dashed red line) and to the east of Beaver Creek. Red numbers identify streams as follows: B-Beaver Creek, EBH-East Branch Hay Creek, H-Hay Creek, and LB-Little Beaver Creek. Sides of squares in the grid are one mile (1.6 kilometers) and the contour interval is 20 meters

Detailed topographic maps of adjacent areas show additional southeast- and northwest-oriented streams and valleys leading to north-oriented Beaver Creek and suggest Beaver Creek valley headward erosion was across multiple closely spaced and very low gradient southeast-oriented channels. Detailed topographic maps also suggest the north-oriented Little Missouri River valley and the northeast-oriented Yellowstone River valley also eroded headward across numerous and closely spaced southeast-oriented channels. To the east of the north-oriented Little Missouri River valley are headwaters of the southeast-oriented Cannonball and Heart Rivers, both of which turn in northeast directions to enter the south-oriented Missouri River as barbed tributaries (see figure 1) and the northeast-oriented downstream Heart and Cannonball River valley segments also appear to have captured a major southeast-oriented drainage system. The question then arises as to why numerous closely spaced and low gradient southeast-oriented drainage routes crossed a region now drained by the northeast-oriented Yellowstone River and the north-oriented Little Missouri River and its north-oriented Beaver Creek tributary with the water being captured further to the east by northeast-oriented valley headward erosion?

The closely spaced and low gradient southeast-oriented channels might reasonably have been moving massive icemarginal floods along a continental ice sheet's southwest margin. Water moving in such floods logically would have carved diverging and converging or anastomosing complexes of generally southeast-oriented channels into what must have been a flood-eroded low gradient ice-marginal surface region. When captured by headward erosion of much deeper north- and northeast-oriented valleys the diverging and converging channels would have enabled reversed flow on northwest ends of beheaded southeast-oriented channels to capture flood flow from yet to be beheaded channels further to the south so as to supply the volumes of water needed to erode deep northwest- 
oriented tributary valleys. Headward erosion of the northeast- and north-oriented valleys across such massive southeast-oriented ice-marginal melt water floods would be expected if the melting ice sheet was opening up space in a deep "hole" the continental ice sheet had created and occupied. Such an explanation is consistent with the Beaver Creek tributary orientation evidence and with Clausen's new paradigm, but has not otherwise been discussed in the geology or physical geography literature.

\subsection{Triple Drainage Divide Area at the Beaver Creek Drainage Basin Southern End}

Figure 4 uses a modified topographic map from the USGS National Map website to illustrate escarpments surrounding the Beaver Creek drainage basin's southern end. Beaver Creek originates as a northeast-oriented stream and turns in a northwest direction to reach the northern edge of figure 4 . To the north of figure 4 Beaver Creek turns to flow in a north direction before eventually turning in a northeast direction to enter the deep Little Missouri River valley. The major drainage basins are labeled with Cabin Creek and O'Fallon Creek being northwest-oriented Yellowstone River tributaries and all streams shown in the Little Missouri River drainage basin are tributaries to the north-oriented Little Missouri River. Note how headwaters of northwest-oriented Cabin Creek are oriented in northwest directions and how many O'Fallon Creek tributaries also have northwest orientations. To the east of the Beaver Creek drainage basin note how almost all Little Missouri River tributaries begin as southeastoriented streams.

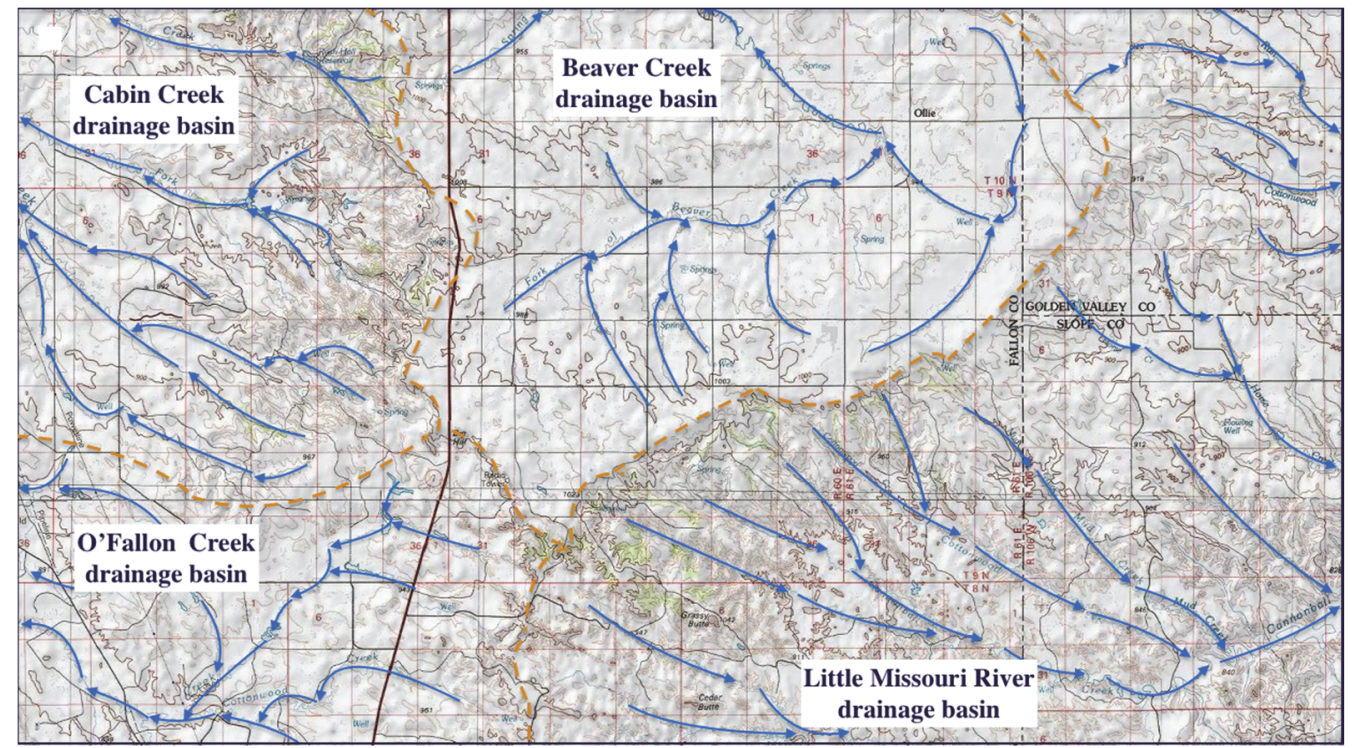

Figure 4. Modified topographic map from the USGS National Map website showing the Beaver Creek drainage basin southern end. Blue arrows emphasize drainage routes and directions and dashed brown lines show major drainage divides. Sides of squares in the grid are one mile (1.6 kilometers) long and the contour interval is 20 meters

To the south of figure 4 the town of Baker, Montana is located on the floor of a broad 100-meter deep or deeper northwest-to-southeast oriented through valley linking northwest-oriented O'Fallon Creek tributary headwaters with headwaters of southeast-oriented Little Missouri River tributary headwaters (at the highway intersection near the Sandstone Creek headwaters seen in figure 2). Drainage divide elevations on the through valley floor are approximately 920 meters while high points in the southern Beaver Creek drainage basin are slightly higher than 1020 meters. To the south of the town of Baker the Yellowstone River-Little Missouri River drainage divide rises in places to more than 1030 meters, but is crossed by less obvious northwest-southeast oriented through valleys (or divide crossings) that also link northwest-oriented Yellowstone River drainage basin streams with southeastoriented Little Missouri River drainage basin streams. To the northwest of figure 4 O'Fallon Creek joins the Yellowstone River at an elevation of approximately 670 meters or 250 meters lower than where the present day through valley near Baker crosses the Yellowstone-Little Missouri River drainage divide. Southeast-oriented streams originating in the Baker area join northeast-oriented Little Beaver Creek (not to be confused with the Little Beaver Creek in the Beaver Creek drainage basin), which then joins the Little Missouri near Marmarth, North Dakota at an elevation of approximately 820 meters or only 100 meters lower than the Yellowstone-Little Missouri River drainage divide elevation near Baker. The drainage divide between northwest-oriented streams flowing to 
the north-oriented Little Missouri River and southeast- and east-oriented streams flowing approximately 300 kilometers to reach the south-oriented Missouri River is located about 15 kilometers to the east of Marmarth and almost everywhere has an elevation of less than 1000 meters.

The 100-meter deep or deeper northwest-to-southeast oriented through valley at Baker and less obvious through valleys crossing the Yellowstone-Little Missouri River drainage divide to the south are northern extensions of previously described and interpreted northwest-to-southeast oriented through valleys. In two separate papers Clausen (2017b, 2018b) argues the numerous and closely spaced northwest-to-southeast divide crossings linking northwest-oriented streams with southeast-oriented streams can only be explained if the north-oriented Little Missouri River valley, the northeast-oriented Boxelder Creek valley (a Little Missouri River tributary located to the south of this paper's study region), the northeast-oriented Little Beaver Creek valley (another Little Missouri River tributary also located to the south of this paper's study region and not to be confused with the Little Beaver Creek in the Beaver Creek drainage basin), and the Powder River valley (a Yellowstone River tributary shown in figure 1) eroded headward in sequence from the east to the west across massive southeast-oriented ice-marginal melt water floods with northwest-oriented Yellowstone River tributaries being formed by reversals of flow on downstream ends of what must have been beheaded low gradient flood flow channels. Immense southeast-oriented ice-marginal melt water floods also explain the 100-meter deep or deeper northwest-to-southeast oriented through valley to the south of the escarpment-surrounded Beaver Creek drainage basin (at Baker) with the southeastoriented flood waters first being captured by headward erosion of the north-oriented Little Missouri River valley and subsequently being beheaded and reversed by headward erosion of the deep northeast-oriented Yellowstone River valley.

\subsection{Comparing the Elevations of the Regional Drainage Divides}

To the northwest of the Beaver Creek drainage basin is a narrow northeast-oriented Yellowstone River drainage basin segment with the high Redwater River-Yellowstone River drainage divide roughly paralleling the northeastoriented Yellowstone River. The Redwater River is a north-oriented Missouri River tributary originating in eastern Montana and flows in a much deeper and larger valley than the river size suggests. Lag gravels and alluvium within the Redwater River drainage basin were observed during field investigations to contain distinctive igneous rock types that had been transported from locations now found within the upstream Yellowstone River drainage basin. Thick alluvial deposits named by Howard (1958) as the Rimroad Gravel and also containing those same distinctive igneous rock types cap the northeast-trending Redwater River-Yellowstone River drainage divide which today stands more than 200 meters above the Redwater River valley floor and more than 300 meters above the Yellowstone River valley floor. The relatively straight northeast-trending drainage divide separates southeastoriented Yellowstone River tributary drainage basins from northwest-oriented Redwater River tributary drainage basins and the drainage divide elevation gradually decreases in a northeast direction from a high point of 1094 meters at Big Sheep Mountain (to the northwest of the Beaver Creek drainage basin southern end).

The Yellowstone River-Beaver Creek drainage divide also gradually decreases in elevation in a north direction from a high point of more than 1020 meters at its southern end and separates northwest-oriented Yellowstone River tributary drainage basins from east- and southeast-oriented Beaver Creek tributary drainage basins. The Beaver Creek-Little Missouri River drainage divide decreases in a north direction from a high point of more than 1020 meters at its southern end and is generally slightly lower in elevation than corresponding points on the Yellowstone River-Beaver Creek drainage divide to the west. Lag gravels and previously mentioned mapped QTU deposits in the Beaver Creek drainage basin contain some of the same distinctive igneous rock types found in the high Rimroad Gravels to the northwest of the deep Yellowstone River valley. To the east of the north-oriented Little Missouri River valley is the Little Missouri River-Missouri River drainage divide, which separates short Little Missouri River tributary drainage basins from southeast-oriented headwaters of long Missouri River tributaries. While isolated buttes stand as much as 200 meters above the Little Missouri River-Missouri River drainage divide, elevations along that drainage divide are generally slightly lower than corresponding elevations along the Beaver Creek-Little Missouri River drainage divide to the west. In other words a good case can be made that regional drainage divide elevations decrease slightly in east and southeast directions with the Redwater River-Yellowstone River drainage divide being slightly higher than the Yellowstone River-Beaver Creek drainage divide, which is slightly higher than the Beaver Creek-Little Missouri River drainage divide, which in turn is slightly higher than the Little Missouri River-Missouri River drainage divide.

\subsection{Evidence for Deep Erosion Along the Beaver Creek-Little Missouri Divide}

Buttes located just to the east of the Beaver Creek-Little Missouri River drainage divide suggest as much as 200 meters of bedrock may have been removed from at least parts of the Beaver Creek drainage basin surface as large 
east- and southeast-oriented ice-marginal melt water floods flowed across the region. Figure 5 illustrates the Beaver Creek-Little Missouri River drainage divide area near Beach, North Dakota. Little Beaver Creek (LB) flows in a north direction adjacent to the drainage divide and to the north of figure 5 turns in a northwest direction to join Beaver Creek (see figure 3). Just to the east of the drainage divide Camels Hump Butte and Sentinel Butte stand high above the surrounding landscape. Remnants of lacustrine deposits containing fossil fish of possible Oligocene to Miocene age (Boyer, 1981) cap Sentinel Butte. The Geologic Map of North Dakota (Clayton, 1980) shows Paleocene sediments under a Miocene cap rock at Sentinel Butte with the Paleocene bedrock extending across much of the region, although a patch of Quaternary and Upper Tertiary Undivided (QTU) material containing distinctive igneous alluvium is shown near the Sentinel Butte base. Field inspection showed the QTU alluvium to be more extensive near the butte base than shown on the North Dakota Geologic Map, although no distinctive igneous alluvium was found on the butte itself.

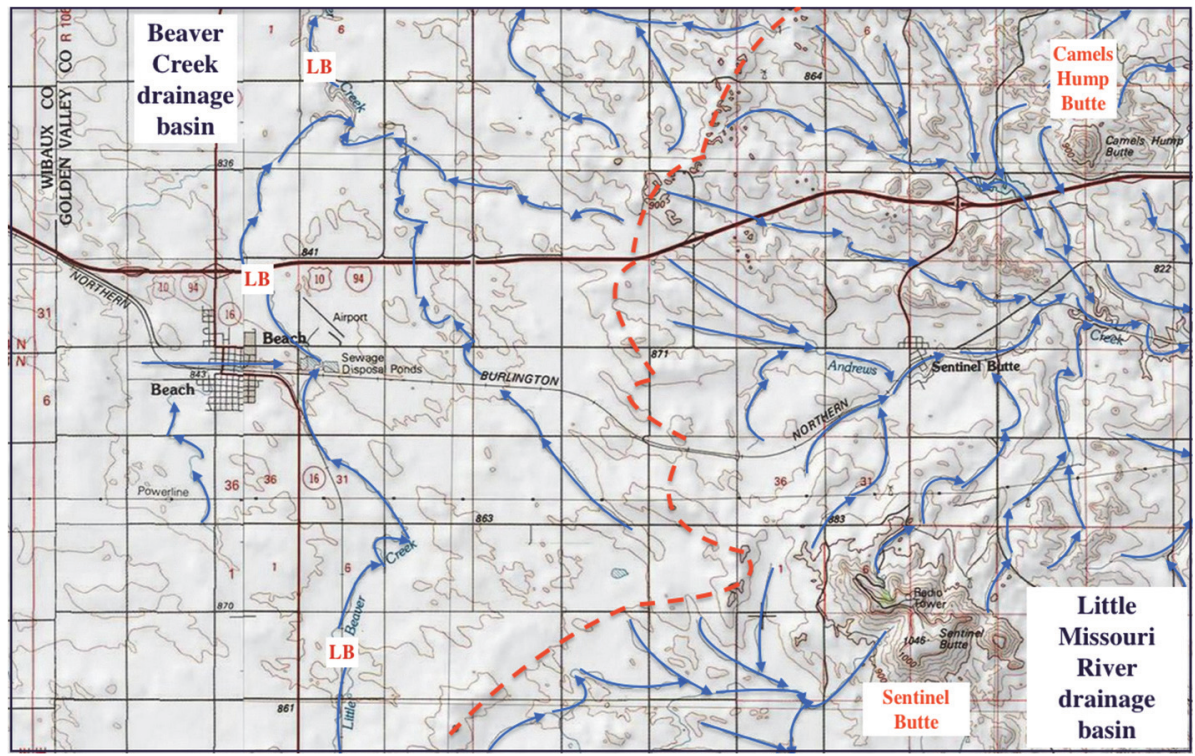

Figure 5. Modified topographic map from the USGS National Map website showing buttes just to the east of the Beaver Creek-Little Missouri River drainage divide (dashed red line). The red letters LB indicate north-oriented Little Beaver Creek, which to the north of figure 5 turns in a northwest direction (see figure 3 ). Sides of squares in the grid are 1 mile or 1.6 kilometers. The contour interval is 20 meters

Most important for determining the Beaver Creek drainage basin erosional history is the fact that Sentinel Butte rises almost 200 meters above the nearby Little Beaver Creek drainage basin surface (although is only 22 meters higher than the highest point at the Beaver Creek drainage basin's southern end). Sentinel Butte (elevation 1045 meters) is one of several isolated buttes rising to elevations slightly greater than 1000 meters now located on both sides of the north-oriented Little Missouri River valley (the Little Missouri River valley is to the east of Sentinel Butte and the valley floor to the east of figure 5 has an elevation of approximately 700 meters). The highest of these isolated North Dakota buttes is White Butte (elevation 1069 meters) and is found to the southeast of Sentinel Butte and on the Little Missouri River valley's eastern side. White Butte, unlike Sentinel Butte is composed of significant thicknesses of mapped White River Group sediments containing well-documented Oligocene vertebrate fossils and coarse-grained alluvium including large quantities of the previously mentioned distinctive igneous rocks. Alluvium containing the distinctive igneous rock types is also found in deposits mapped as QTU (Clayton et al, 1980) near the White Butte base. Rock types in the White River Group and QTU alluvium match those in QTU deposits near the Sentinel Butte base, found in Beaver Creek drainage basin lag gravels, and in the Rimroad Gravel alluvium located across the deep northeast-oriented Yellowstone River valley and on the high Redwater River-Yellowstone River drainage divide.

The isolated buttes and the White River Group conglomerates, QTU alluvial deposits, and lag gravels containing the distinctive igneous rocks document deep regional erosion by large amounts of east-oriented water. The distinctive igneous rock trail upstream from the Rimroad Gravel location suggests the alluvium was transported from south central Montana in a northeast direction before being diverted in an east direction to cross what is now the Beaver Creek drainage basin to reach areas now located to the east of the north-oriented Little Missouri River valley. Initially a large northeast-oriented river or flood must have flowed on a surface at least as high as the highest 
regional buttes today before being (partially?) diverted on that high surface in an east or southeast direction. Differing compositions of bedrock now making up the various isolated buttes suggest narrow valleys were first eroded into the initial high level surface and then partially filled with thick fossil bearing alluvial deposits (and also other sedimentary materials including volcanic ash) now mapped as White River Group. Fossils found in those deposits may have been animals trapped during major flood events and their intact carcasses may have been transported for considerable distances before burial. Following the partial filling of those 150-200 meter deep valleys continued massive eastward flow inverted the topography by removing most of the easily eroded surrounding bedrock and deposited the QTU alluvial debris leaving isolated buttes, including some of the earlier alluvial valley fills as evidence of the higher topographic surface that once existed.

Probably the best clues as to the nature of that previous higher-level topographic surface are the small lacustrine rock outcrops containing fossil fish now located at the Sentinel Butte top. According to Boyer (1981) "the ancient lake in which the sequence [of lacustrine sediments] was deposited underwent several episodes of shrinkage and closure during which salinity increased, followed by expansion accompanied by abrupt development of ectogenic meromixis." The fossil fish suggest water entering the lake during expansion episodes was linked to more permanent water bodies and that at least several episodes of short term flooding refilled the lake. Floods responsible for the lake expansion may have had the same water source and flow routes as the floods that subsequently lowered the surrounding regional landscape. If so the lake probably existed before floodwaters had eroded deep valleys into the region and the floods responsible for deep erosion of the regional landscape may have occurred on an episodic basis. It is possible the episodic flooding was in some way related to continental ice sheet melt water flood events, although not enough evidence remains to exclude other possibilities.

\section{Discussion}

The Beaver Creek drainage basin erosional landforms as described in this paper and the mapped QTU alluvial deposits with distinctive igneous rocks are best explained if immense southeast- and east-oriented floods transported Rimroad Gravel alluvium along a continental ice sheet's southwest margin toward what is now the south-oriented Missouri River valley in south central North Dakota and north central South Dakota. However, much of the published regional geology literature makes such an explanation impossible because the north-oriented Little Missouri River valley and northeast-oriented Yellowstone River valley supposedly predate late Cenozoic North American continental ice sheets and alluvium containing Rimroad Gravel rock types is found in White River Group conglomerates in which well-documented Oligocene fossils are also found (and the commonly accepted regional geology paradigm requires a 30 million year gap between the Oligocene fossil deposition and the continental ice sheet's existence).

Hoganson et al (1998) describe southwest North Dakota White River Group stratigraphy and paleontology. They claim without addressing the distinctive alluvium source that the "Chalky Buttes Member [of the Chadron Formation of the White River Group] is lithologically similar to the Chamberlain Pass Formation in the Big Badlands of South Dakota and Nebraska... and Lillegraven's (1970) 'dazzling white' unit of the Chadron Formation at Slim Buttes, [in northwest] South Dakota." Yet pebbles and cobbles of distinctive igneous rocks are abundant in the southwest North Dakota Chadron Formation and match pebbles and cobbles found in the Beaver Creek drainage basin, the Rimroad Gravels on the Redwater-Yellowstone River drainage divide, and alluvium in Red Lodge Creek that came from the Beartooth Mountains to the southwest of Billings, Montana and do not match rock types found in any South Dakota and Nebraska White River Group stratigraphic units. The Hoganson et al paper is arguing for a commonly held interpretation that the isolated southwest North Dakota White River Group deposits are remnants of one time continuous layers of White River Group sediments that extended from southwest North Dakota across western South Dakota, western Nebraska, and large areas of Wyoming and northeast Colorado (see map in Larson and Evanoff, 1998), but the presence of the distinctive igneous rock alluvium strongly suggests otherwise.

The trails of alluvium containing distinctive igneous rock types (derived from the Beartooth Mountain) pose significant problems for anyone trying to explain them from commonly accepted regional geology paradigm perspective. Papers presenting the commonly published interpretation, like the Hoganson et al (1998) paper, frequently omit any mention of the distinctive igneous rock pebbles and cobbles found in the southwest North Dakota White River Group sediments or suggest, without supporting evidence, the pebbles and cobbles had been transported from a Black Hills source. Such papers assume continuous layers of middle and late Tertiary sediments were laid down one on top of the other over most, or all, of the region where discontinuous White River Group sediments now exist. Such an interpretation also assumes drainage routes similar to the present day north- and northeast-oriented Missouri River tributaries (e.g. Little Missouri River) were responsible for transporting the middle and late Tertiary sediment materials to southwest North Dakota, which is why many vertebrate 
paleontologists, if they make any claims at all, state without any confirming evidence that southwest North Dakota White River Group sediments were derived from a Black Hills source areas.

While still trying to explain the distinctive alluvium trails from the commonly accepted paradigm perspective Clausen (1982) proposed large floods of water from melting Beartooth Mountain alpine glaciers had transported the coarse-grained alluvium in a northeast direction to eastern Montana where a continental ice sheet diverted the water in east and southeast directions. While that hypothesis explained the distinctive alluvium trails it did not explain the alluvium presence in several valleys to the east and north of the continental ice sheet margin, nor did it provide a mechanism for eroding the upstream Little Missouri River and Yellowstone River drainage basin valley systems and as a result had to be rejected. Efforts to find a satisfactory hypothesis kept leading to more and more unexplained evidence and finally to a decision to undertake the Missouri River drainage basin landform origins project, during which detailed topographic maps covering the entire Missouri River drainage basin were systematically studied to determine how Missouri River drainage system valleys originated and evolved.

Study results determined immense floods of probable continental ice sheet origin had flowed across the entire Missouri River drainage basin, which defines the new paradigm starting point. The new paradigm requirement that melt water from a continental ice sheet reached all areas of the present day Missouri River drainage basin is impossible from the commonly accepted geology paradigm perspective and necessitates that the continental ice sheet created and occupied a deep "hole" in the North American continent. This deep "hole" must have been created by a combination of deep glacial erosion and of ice sheet triggered crustal warping, which among other things raised the Rocky Mountains and Rocky Mountain outliers as melt water floods flowed across them, and which also created what is today the upper Missouri River drainage basin's northeast- and north-oriented regional slope. The new paradigm requires a continental sheet to have been present while what the commonly accepted geologic histories consider to have been middle and late Tertiary events were taking place, which means geologic histories developed from the new paradigm perspective are fundamentally different from geologic histories developed from the commonly accepted geologic history paradigm's perspective.

The new paradigm requirements strongly suggest this first continental ice sheet (the ice sheet that created and occupied a deep "hole") eventually stagnated as supra-glacial melt water rivers carved what ultimately became ice-walled and bedrock-floored canyons into the ice sheet surface. The Missouri Escarpment, extending approximately 1000 kilometers from Alberta across Saskatchewan and into North and South Dakota, is interpreted as the southwest wall of one such ice-walled and bedrock-floored canyon. At some point in the ice sheet's melt history the floor of that ice-walled and bedrock-floored canyon became lower in elevation than ice margin areas where immense southeast-oriented ice marginal melt water floods were flowing. While details of the first ice sheet melt history need to be worked out (assuming enough evidence remains to reconstruct details) at least some icemarginal floodwaters spilled across the decaying ice sheet margin and entered the deeper ice-walled and bedrockfloored canyon. Such spillages initiated headward erosion of deep valleys (including the Little Missouri, Yellowstone and Redwater River valleys) from the ice-walled and bedrock-floored canyon floor. Once initiated the deep valleys eroded headward across massive southeast-oriented ice marginal melt water floods, which explains how the north-oriented Little Missouri River valley and its north-oriented Beaver Creek tributary valley eroded across east- and southeast-oriented floods prior to erosion of the northeast-oriented Yellowstone River valley, which occurred prior to erosion of the deep north-oriented Redwater River valley.

The above new paradigm interpretations predict alluvium with rock types matching Rimroad Gravel rock types should be found in the Beaver Creek drainage basin area (between the present day Yellowstone and Little Missouri River valleys) and also in southwest North Dakota in addition to locations on the floors of at least some of the former ice-walled and bedrock-floored canyons, which is easily confirmed. However such an interpretation requires conglomerates containing Rimroad Gravel rock types in southwest North Dakota White River Group sediments to have been deposited as valley fills after at least some of the Rimroad Gravel material had been transported to present day eastern Montana. As noted above fossils in those southwest North Dakota White River Group sediments have been correlated with fossils elsewhere, specifically in western South Dakota, Nebraska, and Wyoming White River Group sediment locations. It is possible the discontinuous White River Group sediments at those other locations were also deposited as valley fills, perhaps even during immense melt water floods, although such an interpretation would require radical changes in the way those other White River Group sediments have been interpreted to date.

\section{Conclusions}

Beaver Creek drainage basin and adjacent region erosional landform origins as seen on detailed topographic maps can be explained by large southeast- and east-oriented floods flowing along a continental ice sheet's southwest 
margin. This explanation is based on a new paradigm perspective, which requires the north-oriented Little Missouri River valley and its north-oriented Beaver Creek tributary valley to have eroded headward across the ice-marginal floods prior to headward erosion of the northeast-oriented Yellowstone River valley. The same east- and southeastoriented ice-marginal floods also explain alluvium mapped on the Geologic Map of North Dakota as QTU (Quaternary and Tertiary Undivided), found in and adjacent to the Beaver Creek drainage basin to the west of the Little Missouri River valley and in southwest North Dakota to the east of the deep Little Missouri River valley, and which contains distinctive rock types found in the Rimroad Gravels on the Yellowstone-Redwater River drainage divide (to the west and northwest of the Beaver Creek drainage basin and of the deep Yellowstone River valley). Alluvium containing similar igneous rock types is also found in southwest North Dakota White River Group sediments, which complicate explanations from the commonly accepted paradigm perspective. Those White River Group sediments also contain well-document Oligocene fossils, which complicate explanations from the new paradigm perspective. Further work is needed to describe how it is possible for pebbles and cobbles matching Rimroad Gravel rock types and Oligocene age fossils to be found together in southwest North Dakota White River Group sediments, and that description if it does not include massive continental ice sheet ice-marginal melt water floods must also be consistent with the regional erosional landforms evidence described here.

\section{Acknowledgements}

Field work discussed in this paper and initial work on the Missouri River drainage basin landform origins research project was done while employed as a faculty member at Minot State University where other faculty members, library staff members, and some students also greatly assisted in developing and providing access to needed topographic map collections.

\section{References}

Boyer, B. W. (1981). Tertiary lacustrine sediments from Sentinel Butte, North Dakota and their sedimentary record of ectogenic meromixis. Journal of Sedimentary Petrology, 51(2), 429-440.

Carlson, C. G. (1983). Geology of Billings, Golden Valley, and Slope Counties, North Dakota: part 1: North Dakota Geological Survey, Bulletin 76, (plate 1, scale 1:126,720).

Clausen, E. (1982). Evidence for glaciation in southwestern North Dakota and northwestern South Dakota: Proceedings of the North Dakota Academy of Science, 36, 16.

Clausen, E. (2017a). Using map interpretation techniques for relative dating to determine a western North Dakota and South Dakota drainage basin formation sequence, Missouri River drainage basin, USA. Journal of Geography and Geology, 9(4), 1-18. https://doi.org/10.5539/jgg.v9n4p1

Clausen, E. (2017b). Origin of Little Missouri River - South Fork Grand River and nearby Drainage Divides in Harding County, South Dakota and Adjacent Eastern Montana, USA. Open Journal of Geology, 7, 1063-1077. https://doi.org/10.4236/ojg.2017.78071

Clausen, E. (2018a). Belle Fourche River-Cheyenne River drainage divide area in the Wyoming Powder River Basin analyzed by topographic map interpretation methods, USA. Journal of Geography and Geology, 10(2), 1-16. https://doi.org/10.5539/jgg.v10n2p1

Clausen, E. (2018b). Probable deep erosion by continental ice sheet melt water floods: Chalk Buttes area of Carter County, Montana, USA. International Journal of Geography and Geography, Conscientia Beam, 7(1), 14-28.

Clausen, E. N. (1989). Presence of rounded boulders and large cobbles at base of White River Group (Oligocene) strata in southwest North Dakota and northwest South Dakota. Contributions to Geology, University of Wyoming, 27(1), 1-6.

Clayton, L. Bluemle, J. P., \& Carlson, C. G. (1980). Geologic map of North Dakota: North Dakota Geological Survey.

Colton, R. B., \& Fullerton, D. S. (1986). Proglacial lakes along the Laurentide ice sheet margin in Montana. Geological Society of America Abstracts with Programs, 18(5) 347.

Crandell, D.R. (1958). Geology of the Pierre area, South Dakota: United States Geological Survey Professional Paper, 307, 83p.

Denson, N.M., and Gill, J.R. (1965). Uranium-bearing lignite and carbonaceous shale in the southwestern part of the Williston Basin-a regional study. United States Geological Survey Professional Paper, 463, 75p.

Douglas, E. (1909). A geological reconnaissance in North Dakota, Montana, and Idaho; with notes on Mesozoic and Cenozoic geology. Carnegie Museum, Annals, 5, 211-288. 
Duk-Rodkin, A., \& Hughes, O. L. (1994). Tertiary-Quaternary drainage of the pre-glacial MacKenzie River basin. Quaternary International, 22-23, 221-241. https://doi.org/10.1016/1040-6182(94)90015-9

Flint, R. F. (1955). Pleistocene geology of eastern South Dakota: United States Geological Survey Professional Paper, 262, $174 \mathrm{p}$.

Hoganson, J. W., Murphy, E. C., \& Forsman, N. F. (1998). Lithostratigraphy, paleontology, and biochronolgy of the Chadron, Brule, and Arikaree Formations in North Dakota. In Terry, D.O. LaGarry, H.E., and Hunt, R.M. (Eds.), Depositional environments, lithosrtatigraphy, and biostratigraphy of the White River and Arikaree Groups (Late Eocene to Early Miocene, North America): Geological Society of America Special Paper, 325, 185-196.

Howard, A. D. (1958). Drainage evolution in northeastern Montana and northwestern North Dakota. Bulletin Geological Society of America, 66, 575-586. https://doi.org/10.1130/00167606(1958)69[575:DEINMA]2.0.CO;2

Howard, A. D. (1960). Cenozoic history of northeastern Montana and northwestern North Dakota with emphasis on the Pleistocene: United States Geological Survey Professional Paper 326, 107p.

Kuhn, T. (1965). The Structure of Scientific Revolutions: Second edition, enlarged: University of Chicago Press, $210 \mathrm{p}$.

Larson, E. E., \& Evanoff, E. (1998). Tephrostratigraphy and source of the tuffs of the White River sequence. In Terry, D.O. LaGarry, H. E., and Hunt, R. M. (Eds.), Depositional environments, lithosrtatigraphy, and biostratigraphy of the White River and Arikaree Groups (Late Eocene to Early Miocene, North America). Geological Society of America Special Paper, 325, 185-196. https://doi.org/10.1130/0-8137-2325-6.1

Lillegraven, J. A. (1970). Stratigraphy, structure, and vertebrate fossils of the Oligocene Brule Formation, Slim Buttes, northwestern South Dakota. Geological Society of America Bulletin, 81, 831-850. https://doi.org/10.1130/0016-7606(1970)81[831:SSAVFO]2.0.CO;2

McMillan, J. N. (1973). Shelves of the Labrador Sea and Baffin Bay, Canada. Canadian Society of Petroleum Geologists Memoir, 1, 473-515.

Russell, W. L. (1929). Drainage alignment in the western Great Plains. Journal of Geology, 37, 249-255. https://doi.org/10.1086/623618

Sears, J. W. (2013). Late Oligocene-early Miocene Grand Canyon. A Canadian connection? GSA Today, 23(11), 4-10. https://doi.org/10.1130/GSATG178A.1

Shurr, G. W. (1982). Geological significance of lineament interpreted from Landsat images near the northern Black Hills. In Christopher, J. E. and Kaldi, J. (Eds.). Fourth International Williston Basin Symposium. Saskatchewan Geological Society Special Publication, 6, 313-320.

Stone, W. J. (1973). Stratigraphy and sedimentary history of middle Cenozoic (Oligocene and Miocene) deposits in North Dakota: University of North Dakota PhD thesis, 217p.

Thornbury, W. D. (1965). Regional Geomorphology of the United States: John Wiley and Sons, New York, 609 p.

Vuke, S. M., \& Colton, R. B. (1998). Geologic map of the Glendive 30' x 60' quadrangle, eastern Montana and adjacent North Dakota: Montana Bureau of Mines and Geology, Open-File Reports MBMG-371, scale $1: 100,00$.

Vuke, S. M., Wilde, E. M., Colton, R. B., \& Stickney, M. C. (2003). Geological map of the Wibaux 30' x 60' quadrangle, eastern Montana and adjacent North Dakota: Montana Bureau of Mines and Geology, Open-File Reports MBMG-465, scale 1:100,000.

Whitney, M. L. (1985). Yardangs. Journal of Geological Education 33, 93-100. https://doi.org/10.5408/0022$1368-33.2 .93$

\section{Copyrights}

Copyright for this article is retained by the author(s), with first publication rights granted to the journal.

This is an open-access article distributed under the terms and conditions of the Creative Commons Attribution license (http://creativecommons.org/licenses/by/4.0/). 